\title{
. PELATIHAN PADJADJARAN-MAYEROFF CARING PRINCIPLES (PMCP) UNTUK MENINGKATKAN PENGETAHUAN IBU MENGENAI PRINSIP-PRINSIP PENDAMPINGAN TERHADAP ANAK MILD INTELLECTUAL DISABILITY USIA 7-10 TAHUN
}

\author{
Vindya Anjar Pramesti, Langgersari Elsari Novianti, Hendriati Agustiani \\ Fakultas Psikologi Universitas Padjadjaran, Bandung \\ Jl. Raya Bandung Sumedang KM.21 Kabupaten Sumedang, Jawa Barat 45363 \\ Email: vindyanjar@yahoo.com
}

\begin{abstract}
ABSTRAK. Penelitian ini dilakukan guna memperoleh rancangan dan melaksanakan ujicoba program pelatihan Padjadjaran-Mayeroff Caring Principles (PMCP) yang mampu meningkatkan pengetahuan ibu mengenai prinsip pendampingan terhadap anak mild intellectual disability usia 7-10 tahun. Penelitian ini menggunakan teori dasar pendampingan yang disampaikan oleh Milton Mayeroff (1971) sebagai bahan acuan untuk pembuatan modul. Pelatihan dirancang menggunakan pendekatan instructional design, proses validasi dilakukan melalui review oleh dua orang psikolog. Ujicoba pada penelitian ini menggunakan metode kuasi eksperimen dengan rancangan one group pretest posttest. Ujicoba dilakukan guna memperoleh hasil jika modul yang telah dibuat mampu untuk meningkatkan pengetahuan ibu yang memiliki anak mild intellectual disability. Teknik sampling yang digunakan adalah purposive sampling; terdapat empat orang ibu yang menjadi responden penelitian ini. Alat ukur yang digunakan adalah prinsip pendampingan yang diturunkan dari teori Milton Mayeroff (1971). Alat ukur ini sudah divalidasi oleh dua orang psikolog, diuji coba, dan nilai reliabilitasnya $\alpha=0.904$. Hasil penelitian menunjukkan bahwa terdapat peningkatan nilai selama mengikuti pelatihan yang ditunjukkan dari nilai pretest dan posttest. Ibu-ibu responden mengalami peningkatan pengetahuan mengenai prinsip-prinsip pendampingan anak dengan mild intellectual disability sebanyak $21 \%$.
\end{abstract}

Kata kunci: pelatihan; pengetahuan; prinsip pendampingan anak; mild intellectual disability

\section{PADJADJARAN-MAYEROFF CARING PRINCIPLES (PMCP) TRAINING PROGRAM TO IMPROVE MOTHER'S KNOWLEDGE ON CARING PRINCIPLES FOR CHILDREN WITH MILD INTELLECTUAL DISABILITY AGE 7-10 YEARS OLD}

\begin{abstract}
This research was carried out to obtain and pilot tests the Padjadjaran-Mayeroff Caring Principles (PMCP) Training Program that can increase mother's knowledge on caring principles for children with mild intellectual disability age 7-10 years old. This research used the basic theory of caring by Milton Mayeroff (1971) as reference material for the manufacture of modules. Try out that used in this research is one group pre-test post-test quasi experiment method. The training was designed using instructional design approach and has validated by two psychologist. The tests are conducted in order to obtain results if the module has been created to be able to improve the knowledge of mothers who have children with mild intellectual disability. This process involved four subjects obtained by using purposive sampling technique. This research was using developed caring principles by Milton Mayeroff (1971) as a measuring instrument. This measurement has validated by two psychologist with $\alpha=0.904$. The result shows there is $21 \%$ significant increase of mother's knowledge about caring principles for children with mild intellectual disability. This number shows if there is an increase value for the indicated training of pretest and posstest.
\end{abstract}

Keywords: training; knowledge; caring principles; mild intellectual disability

\section{PENDAHULUAN}

Perbedaan kemampuan berpikir anak mild intellectual disability belum jelas teramati sebelum anak duduk di Sekolah Dasar. Di usia sekolah, mereka menunjukkan kesulitan dalam berbagai keterampilan akademik seperti membaca, menulis, berhitung, sehingga dibutuhkan guru pendamping dalam pengajarannya. Secara fisik, anak dengan mild intellectual disability pada umumnya tidak memiliki perbedaan dibandingkan dengan anak seusianya. Usia 7-10 tahun merupakan usia awal anak masuk sekolah dan beradaptasi dengan tuntutan yang ada di sekolah. Pada usia ini, umumnya anak dengan mild intellectual disability baru menampilkan beberapa perbedaan dengan anak seusianya terutama dalam kemampuan akademik (Jacobson \& Mulick, 1996).

Anggraini (2010) menjelaskan jika secara sosial mereka mungkin akan menampilkan perilaku yang tidak matang dibandingkan usia kronologisnya. Mereka terkadang kesulitan dalam meregulasi emosi serta perilakunya. Pada umumnya mereka juga lebih senang atau nyaman untuk bermain dengan anak yang usia kronologisnya berada di bawahnya. Mereka mudah untuk dipengaruhi dan cenderung melakukan sesuatu tanpa adanya pertimbangan terlebih dahulu. Selain itu, anak dengan intellectual disability juga memiliki kesulitan untuk 
mengurus dirinya sendiri sehingga ia masih membutuhkan bantuan dalam melakukan tugas bantu diri. Menurut DSM-V (2013) dijelaskan setidaknya ada tiga kriteria seseorang dapat dikatakan intellectual disability, yaitu (a) kurangnya fungsi intelektual; (b) kurangnya fungsi adaptasi; (c) terhambatnya fungsi intelektual dan adaptasi selama masa perkembangan. Jika ditelaah melalui kurva normal, anak dengan mild intellectual disability merupakan anak yang mengalami penyimpangan dua standar deviasi, yaitu IQ di bawah 70 dan di atas 55 (menurut skala Weschler).

Adanya defisit intelektual yang dimiliki oleh anak membuat ia mengalami kesulitan untuk menyelesaikan tugas akademik serta berinteraksi dengan teman sebayanya. Tidak jarang anak dengan mild intellectual disability pada akhirnya merasa dikucilkan dan dijauhi oleh teman-temannya. Selain itu, mereka juga kerap kali mengalami perundungan (bullying) seperti diejek dan dimanipulasi. Pada usia ini, anak mengalami perkembangan psikososial industry vs inferiority; ketika anak tidak melalui tahapan perkembangan ini dengan baik, maka anak akan merasa rendah diri dan putus harapan; tidak jarang pula anak akan menarik diri dari teman seusianya (Issawi \& Dauphin, 2017).

Meski demikian, kemampuan dan perilaku anak dengan mild intellectual disability dapat berkembang dan ditingkatkan apabila tersedia lingkungan yang mampu menstimulasi dan memberi dukungan khususnya dari orang tua ataupun caregiver lainnya (Blair, Greenberg \& Cnic, 2001 dalam Mash \& Wolfe, 2005). Diharapkan ketika ibu mengetahui keterbatasan yang dimiliki oleh anaknya, ibu dapat membantu anak untuk mengoptimalkan kemampuan yang anak miliki. Efektivitas berbagai program penanganan dan peningkatan kemampuan hidup anak dengan intellectual disability sangat ditentukan oleh peran serta dan dukungan penuh dari keluarga. Hal ini dikarenakan keluarga merupakan pihak yang mengenal dan memahami berbagai aspek dalam diri anak melebihi orang lain (Heward, 2003, dalam Vani, Raharjo $\&$ Hidayat, 2015)

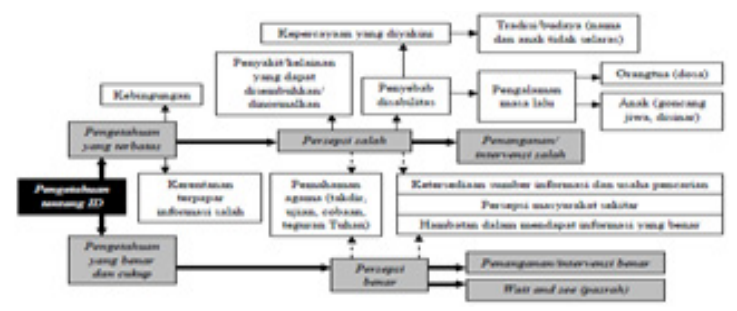

Bagan 1. Persepsi Keluarga Terhadap Anak dengan Mild Intellectual Disability ID

Sumber : lidanial (2016)
Berdasarkan bagan 1 dapat dijelaskan jika pengetahuan tentang intellectual disability yang terbatas akan mengakibatkan kebingungan, kecenderungan untuk memeroleh informasi yang salah, dan persepsi yang salah sehingga mengakibatkan penanganan maupun intervensi yang keliru dari orangtua terhadap anak dengan intellectual disability. Beberapa orang tua masih awam dan kurang memiliki pengetahuan mengenai intellectual disability sehingga orang tua menjadi mudah terpengaruh oleh persepsi masyarakat di lingkungan sekitarnya. Akibatnya, kemampuan anak justru tidak dapat dioptimalkan dengan baik. Hal ini justru memperparah kondisi anak dengan intellectual disability. Kurangnya pengetahuan orang tua ini dapat diakibatkan dari kurangnya ketersediaan sumber informasi dan hambatan dalam mendapat infomasi yang benar.

Beberapa orang tua mengaku jika kurang memahami dan mengetahui kondisi anak mild intellectual disability dan pendampingan yang seharusnya mereka lakukan untuk membantu anak agar berkembang lebih optimal. Guna mendapatkan asesmen kebutuhan maka dilakukan wawancara awal dengan enam ibu yang memiliki anak dengan mild intellectual disability dapat diketahui jika ibu tidak tahu bagaimana cara untuk mendampingi ataupun mendidik anak dengan mild intellectual disability. Ketika ibu belum mengetahui ciri dan karakteristik yang ditampilkan oleh anak merupakan kondisi dari anak mild intellectual disability; sikap yang ditampilkan oleh ibu dalam mendampingi anak menjadi kurang tepat. Misalnya, ibu meminta anak untuk melakukan sesuatu namun dengan bahasa yang tidak konkret sehingga anak tidak dapat melakukan hal yang diminta oleh ibu karena anak tidak memahami bahasa yang disampaikan ibu.

Dampak lain yang diperoleh anak ketika ibu tidak mengetahui kondisi anak mild intellectual disability adalah ibu memiliki harapan yang tinggi terhadap anak, sehingga ibu akan memaksa anak untuk memenuhi standar kemampuan akademik sesuai dengan teman seusianya. Hal ini membuat anak merasa tertekan dan semakin menghindari tugas-tugas yang berkaitan dengan akademik. Ketidaktahuan ibu mengenai kondisi anak mild intellectual disability dan bagaimana cara pendampingan yang tepat bagi mereka, perlu dibantu dengan cara memberikan intervensi guna meningkatkan pengetahuan ibu mengenai cara pendampingan terhadap anak mild intellectual disability.

Pendampingan merupakan suatu metode atau pendekatan yang dilakukan dengan tujuan untuk meningkatkan kualitas hidup seseorang. Mayeroff (1971) menjelaskan jika dalam merawat orang lain, mereka (pengasuh/pendamping/perawat) tidak bisa me- 
maksakan orang lain (yang diasuh/didampingi/dirawat) untuk mengikuti arahannya, melainkan mengikuti arahan perkembangan dari orang (yang diasuh/didampingi) itu sendiri. Dalam pendampingan, sebaiknya pihak yang mendampingi memiliki pengetahuan mengenai karakteristik individu yang didampingi dan cara yang tepat untuk mendampinginya. Dengan demikian, pada fenomena ini, ibu yang memiliki anak dengan mild intellectual disability seharusnya memahami karakteristik anak dan cara yang tepat mendampinginya. Meningkatnya pengetahuan orang tua khususnya ibu mengenai kondisi anak serta pendampingan yang tepat diharapkan meningkatkan kemampuan ibu untuk mendampingi dan mendidik anak, sehingga anak dengan mild intellectual disability dapat berkembang secara optimal.

Berdasarkan hasil analisa need assessment, peneliti tertarik untuk merancang dan memberikan pelatihan pada ibu yang diberi judul Padjadjaran-Mayeroff Caring Principles (selanjutnya akan disingkat menjadi PMCP). Pelatihan PMCP ini berguna untuk meningkatkan pengetahuan ibu mengenai pendampingan terhadap anak mild intellectual disability. Tujuan penelitian ini mengacu pada taxonomy of educational dari Bloom (1956) yang telah direvisi oleh Anderson dan Krathwohl (2001), yaitu pada ranah kognitif. Adapun delapan prinsip pendampingan Mayeroff yang diberikan adalah knowing, alternating ryhtms, patience, honesty, trust, humility, hope, and courage. Knowing yaitu ibu memahami kelebihan dan kekurangan anak. Alternating rhythms yaitu ibu mampu menerapkan cara yang berbeda-beda dalam mendampingi anak yang ditinjau dari pengalaman masa lalu dan hasil pengalamannya tersebut. Patience yaitu ibu mungkin dapat menjadi salah satu faktor penghambat anak untuk tumbuh dan berkembang, oleh karena itu butuh kesabaran. Honesty yaitu sikap objektif ibu dalam memandang kondisi anak. Trust yaitu percaya akan kemampuan yang dimiliki oleh anak. Humility yaitu ibu lebih mengapresiasi kelebihan dan kekurangan yang dimiliki oleh anak sehingga anak dapat lebih percaya diri. Hope yaitu ibu dapat membantu mengoptimalkan tumbuh kembang anak tanpa terpengaruh oleh harapan atau ekspektasi diluar kemampuan anak. Courage yaitu keberanian ibu untuk mendampingi anak ditinjau dari trial and error selama proses pendampingan terjadi.

\section{METODE}

Rancangan penelitian ini terdiri dari dua tahapan, yaitu merancang dan melakukan uji coba rancangan program pelatihan mengenai prinsip-prinsip pendampingan guna meningkatkan pengetahuan ibu mengenai pendampingan terhadap anak mild intellectual disability usia 7-10 tahun. Metode perancangan program pelatihan menggunakan pendekatan instructional design (Morrison, Ross, \& Kemp, 2001). Terdapat 9 tahap yang dijelaskan dalam merancang program dengan menggunakan pendekatan ini, yaitu :

\section{Instructional Problem}

Bertujuan untuk mengidentifikasi masalah dan menentukan tujuan secara lebih spesifik dalam merancang suatu program. Pada tahap ini dilakukan asesmen kebutuhan yang digunakan sebagai alat untuk mengidentifikasi masalah, menentukan tujuan dan memilih bentuk program pelatihan yang sesuai. Asesmen kebutuhan pada penelitian ini dilakukan kepada 6 (enam) orang ibu yang memiliki anak mild intellectual disability. Berdasarkan hasil wawancara didapatkan simpulan bahwa kebutuhan partisipan adalah adanya kegiatan yang bertujuan untuk meningkatkan pengetahuan ibu mengenai pendampingan yang tepat bagi anak mild intellectual disability.

\section{Learner Characteristic}

Karakteristik peserta pada penelitian ini adalah ibu yang memiliki anak Mild Intellectual Disability yang berusia 7-10 tahun dan belum pernah mengikuti pelatihan sebelumnya. Hal ini sesuai dengan tujuan penelitian yang hendak meningkatkan pengetahuan ibu dengan anak mild intellectual disability mengenai cara-cara mendampingi anak dengan mild intellectual disability.

\section{Task Analysis}

Pada proses perancangan diperlukan adanya tujuan yang perlu dicapai oleh partisipan setelah mengikuti suatu program pelatihan. Pelatihan ini bertujuan untuk meningkatkan pengetahuan ibu mengenai prinsip-prinsip pendampingan, maka diharapkan ibu dapat mendampingi anak untuk tumbuh lebih optimal dengan keterbatasan yang mereka miliki.

\section{Instructional Objectives}

Pada penelitian ini, tujuan umum pelatihan didasarkan pada domain kognitif. Ibu, yang menjadi partisipan kegiatan pelatihan ini, diharapkan memiliki pengetahuan mengenai prinsip-prinsip mendampingi anak dengan mild intellectual disability. Pemahaman yang dimiliki ibu diharapkan dapat membantu dan mendampingi anak lebih optimal. Tujuan instruksional umum penelitian ini adalah meningkatkan pengetahuan ibu mengenai prinsip pendampingan anak dengan mild intellectual disability usia 7-10 tahun. Berdasarkan tabel 1 dapat dijelaskan mengenai tujuan instruksional khusus. 
Tabel 1. Tujuan Instruksional Khusus

\begin{tabular}{|c|c|}
\hline $\begin{array}{l}\text { Hasil Need } \\
\text { Assessment }\end{array}$ & Tujuan Instruksional Khusus (TIK) \\
\hline \multirow{4}{*}{$\begin{array}{l}\text { Ibu belum memi- } \\
\text { liki pengetahuan } \\
\text { mengenai mild } \\
\text { intellectual } \\
\text { disability }\end{array}$} & $\begin{array}{l}\text { 1. Partisipan mengetahui mengenai } \\
\text { mild intellectual disability }\end{array}$ \\
\hline & $\begin{array}{l}\text { 2. Partisipan mengetahui tingkatan } \\
\text { dalam intellectual disability khususnya } \\
\text { pada tingkat ringan }\end{array}$ \\
\hline & $\begin{array}{l}\text { 3. Partisipan memahami bagaimana } \\
\text { kondisi anak mild intellectual disability }\end{array}$ \\
\hline & $\begin{array}{l}\text { 4. Partisipan memahami penyebab } \\
\text { munculnya berbagai perilaku yang } \\
\text { ditampilkan oleh anak dan bagaimana } \\
\text { peran ibu dalam pendampingan terha- } \\
\text { dap anak }\end{array}$ \\
\hline \multirow{10}{*}{$\begin{array}{l}\text { Ibu belum } \\
\text { memahami } \\
\text { bagaimana cara } \\
\text { pendampingan } \\
\text { yang tepat bagi } \\
\text { anak mild intel- } \\
\text { lectual disability }\end{array}$} & $\begin{array}{l}\text { 1. Partisipan mengetahui kondisi anak } \\
\text { saat ini }\end{array}$ \\
\hline & $\begin{array}{l}\text { 2. Partisipan mengetahui bagaimana } \\
\text { menerapkan cara yang berbeda dalam } \\
\text { mendampingi anak guna mencapai } \\
\text { tujuan tertentu }\end{array}$ \\
\hline & $\begin{array}{l}\text { 3. Partisipan mengetahui pentingnya } \\
\text { kesabaran dalam proses pendampingan }\end{array}$ \\
\hline & $\begin{array}{l}\text { 4. Partisipan mengetahui pentingnya } \\
\text { ketulusan hati dimana ibu mampu } \\
\text { menilai anak secara objektif }\end{array}$ \\
\hline & $\begin{array}{l}\text { 5. Partisipan mengetahui pentingnya } \\
\text { pemberian kepercayaan kepada anak }\end{array}$ \\
\hline & $\begin{array}{l}\text { 6. Partisipan mengetahui pentingnya } \\
\text { ketulusan dan kerendahan hati dalam } \\
\text { pendampingan }\end{array}$ \\
\hline & $\begin{array}{l}\text { 7. Partisipan mengetahui pentingnya } \\
\text { menerima kondisi anak tanpa memak- } \\
\text { sakan harapan yang tinggi }\end{array}$ \\
\hline & $\begin{array}{l}\text { 8. Partisipan mengetahui pentingnya } \\
\text { keberanian untuk lebih terbuka dan } \\
\text { peka pada apa yang sedang terjadi saat } \\
\text { ini }\end{array}$ \\
\hline & $\begin{array}{l}\text { 9. Partisipan memahami prinsip-prin- } \\
\text { sip pendampingan yang tepat dalam } \\
\text { mendampingi anak mild intellectual } \\
\text { disability }\end{array}$ \\
\hline & $\begin{array}{l}\text { 10. Partisipan mampu mengaplikasikan } \\
\text { prinsip-prinsip pendampingan ke dalam } \\
\text { suatu situasi praktis }\end{array}$ \\
\hline
\end{tabular}

\section{Content Sequencing}

Penyusunan konten dalam penelitian ini mempertimbangkan tingkat kesulitan materi, minat partisipan, pengetahuan yang menjadi prasyarat, dan perkembangan kognitif dari partisipan. Penyusunan ini didasarkan pada kebutuhan partisipan. Penyusunan urutan konten materi yang diberikan dalam program pelatihan ini dilakukan berdasarkan prinsip-prinsip pendampingan (Mayeroff, 1971). Kedelapan sesi materi akan disajikan selama 2 kali pertemuan. Sebelum pemberian sesi akan diberikan lembar pretest. Kemudian di setiap akhir pertemuan diberikan posttest guna melihat sejauhmana pemahaman ibu terhadap materi yang telah diberikan.

\section{Instructional Strategies}

Tahapan ini berisi panduan untuk menentukan bagaimana konten pembelajaran disajikan kepada partisipan. Pelatihan ini menggunakan pendekatan andragogi (Knowles, 2005) sebagai strategi pembelajaran orang dewasa. Lawson (2006) juga menjelaskan beberapa strategi pembelajaran agar menunjang partisipan untuk terlibat dalam kegiatan pembelajaran yang aktif. Ada beberapa metode yang digunakan dalam pelatihan ini, yaitu ceramah, diskusi, roleplay, games, dan studi kasus. Penataan ruangan pelatihan menggunakan $u$-shape, hal ini dikarenakan bentuk tersebut dianggap sesuai bagi pelatihan dengan tipe kelompok kecil yang memungkinkan para partisipan mendapatkan kesempatan yang sama untuk memperhatikan ataupun berdiskusi.

\section{Designing The Message}

Dalam hal ini teknik yang digunakan untuk menyiapkan partisipan terhadap proses pembelajaran adalah dengan adanya overview di awal pertemuan dengan partisipan. Overview digunakan untuk memberikan gambaran dari pembelajaran yang disampaikan sehingga partisipan mengetahui materi yang akan mereka pelajari selama pelatihan dilakukan. Selain overview di sesi awal, pada setiap awal sesi juga dilakukan review terhadap materi yang telah diberikan sebelumnya. Review ini dilakukan guna melihat sejauh mana pengetahuan yang telah diberikan masih diingat oleh partisipan. Dalam penelitian ini, materi diberikan dalam bentuk powerpoint dan kepada partisipan diberikan handout. Pemberian handout diharapkan dapat membantu partisipan dalam mengingat konsep yang telah diberikan.

\section{Development of Instructional Material}

Perencanaan difokuskan pada cara menyampaikan materi sehingga membuat partisipan mampu mencapai tujuan umum dan khusus yang telah dirancang. Oleh karena itu, materi dan material yang akan digunakan guna menunjang penyampaian materi adalah sebagai berikut: (1) slide (berisi materi yang akan disampaikan sehingga partisipan mampu memahami penjelasan yang diberikan, (2) handout (berupa buku yang digunakan penyaji sebagai panduan selama pemberian program pelatihan), (3) tayangan video, guna membantu mem- 
berikan contoh konkret pada partisipan, (4) laptop dan infocus (alat bantu untuk penyajian slide), (5) kamera atau handycam (alat bantu untuk merekam aktivitas selama program pelatihan berlangsung).

\section{Evaluation Instrument}

Terdapat dua macam evaluasi, yaitu evaluasi program dan evaluasi reaksi. Evaluasi program diberikan untuk menentukan efektivitas dari suatu program pelatihan yang telah dirancang (Kirkpatrick, 2008). Sedangkan evaluasi reaksi guna melihat pengaruh atau reaksi dari partisipan terhadap program pelatihan (Kirkpatrick, 2007). Instrumen evaluasi yang digunakan dalam penelitian ini adalah alat ukur pengetahuan ibu (Mayeroff, 1971), kuesioner reaksi partisipan selama pelatihan, dan lembar observasi partisipan pelatihan. Alat ukur ini dibuat dengan tujuan mengukur pengetahuan yang dimiliki oleh partisipan mengenai intellectual disability dan prinsip pendampingan anak mild intellectual disability usia 7-10 tahun yang diturunkan dari teori Mayeroff. Peneliti membagi kuesioner menjadi dua jenis soal, yaitu benar-salah dan pilihan ganda yang kemudian dilakukan uji validitas maupun reliabilitasnya. Pengukuran validitas menggunakan metode evidence for validity on content, yaitu validitas aitem kuesioner diuji dengan cara melihat keterikatan antara aitem dengan konstruk teori yang dilakukan oleh ahli (Goodwin, 2010). Setelah alat ukur selesai divalidasi, dilanjutkan dengan uji reliabilitas. Uji reliabilitas kuesioner ini diukur menggunakan rumus Kuder Richardson 20 dengan bantuan Excel. Adapun hasil reliabilitas alat ukur ini adalah $\alpha=0,904$.

Setelah dilakukan perancangan program pelatihan, maka dilakukan tahapan kedua dari penelitian ini yaitu uji coba rancangan program pelatihan. Uji coba dilakukan untuk mendapatkan data empiris mengenai materi maupun metode serta reaksi partisipan yang dapat digunakan sebagai bahan acuan revisi bagi rancangan program. Desain penelitian yang digunakan pada tahapan ini adalah one group pretest-posttest design, yaitu dengan melakukan pengukuran sebelum dan sesudah perlakuan untuk melihat hasil perlakuan (Christensen, 2011). Selain itu, Graziano \& Raulin (2014) menambahkan jika subjek akan menjadi pembanding bagi dirinya sendiri, yaitu dengan cara membandingkan nilai sebelum dan sesudah eksperimen berlangsung, dengan demikian hasil yang diperoleh dapat menunjukkan ada atau tidaknya hasil dari eksperimen pada tiap subjek.

Desain penelitian ini terdiri atas beberapa langkah, yaitu:

1. Pretest: Pengukuran awal mengenai prinsip pen- damp ingan sebelum melakukan treatment dengan menggunakan alat ukur pengetahuan prinsip pendampingan berdasarkan Mayeroff (1971)

2. Treatment: Pemberian treatment berupa pelatihan prinsip pendampingan dilakukan sebanyak 2 kali

3. Posttest: Pengukuran akhir mengenai prinsip pendampingan setelah melakukan treatment dengan menggunakan alat ukur pengetahuan prinsip pendampingan berdasarkan Mayeroff (1971).

\section{Variabel Penelitian}

Terdapat 2 variabel penelitian yang digunakan dalam penelitian ini, yaitu (1) pelatihan prinsip pendampingan dan (2) pengetahuan prinsip pendampingan.

\section{Variabel Bebas}

Variabel bebas yang digunakan dalam penelitian ini adalah pelatihan untuk meningkatkan pengetahuan ibu mengenai prinsip-prinsip pendampingan pada anak mild intellectual disability usia 7-10 tahun.

\section{Definisi Konseptual}

"A planned process to modify attitude, knowledge or skill behaviour through a learning experience to achieve effective performance in any activity or range of activities. Its purpose, in the work situation, is to develop the abilities of the individual and to satisfy current and future manpower needs of the organization". (Manpower Services Commission (MSC), U.K., 1981 dalam Masadeh, 2012).

Berdasarkan dari penjelasan diatas dapat disimpulkan jika pelatihan merupakan suatu proses untuk memodifikasi suatu perilaku, pengetahuan atau ketrampilan perilaku melalui suatu pengalaman belajar untuk mencapai performa yang efektif dalam berbagai aktivitas.

\section{Definisi Operasional:}

Pelatihan dalam penelitian ini merupakan kegiatan sistematis yang diberikan dengan tujuan untuk meningkatkan pengetahuan ibu mengenai prinsip pendampingan anak mild intellectual disability usia 7-10 tahun dengan menyesuaikan pada karakteristik orang dewasa sebagai partisipan pelatihan dan memungkinkan partisipan untuk turut serta dan berperan secara aktif dalam menetapkan apa, bagaimana, dan kapan mereka belajar.

\section{Variabel Terikat}

Variabel terikat yang digunakan dalam penelitian ini adalah pengetahuan ibu mengenai prinsip pendampingan menurut Mayeroff (1971) terhadap anak mild intellectual disability usia 7-10 tahun. 


\section{Definisi Konseptual}

"Knowledge is a concept. Something that you cannot see it, but can only observe its effects".(Hunt, 2003)

Berdasarkan dari penjelasan diatas dapat disimpulkan jika pengetahuan merupakan sebuah konsep. Sesuatu yang tidak dapat dilihat, namun hanya dapat diobservasi dari dampak yang dihasilkan. Pendampingan yang dimaksud dalam Mayeroff (1971) adalah:

"Caring is a process, a way of relating to someone that involves development, in the same way that friendship can only emerge in time through mutual trust and a deepening and qualitative transformation of the relationship."

Berdasarkan penjelasan diatas dapat disimpulkan pendampingan adalah sebuah proses, cara untuk berhubungan dengan seseorang yang melibatkan perkembangan, dengan cara yang sama seperti persahabatan yang hanya bisa muncul atau tumbuh seiring berjalannya waktu melalui transformasi seperti saling percaya dan hubungan kualitatif yang mendalam. Oleh karena itu, pengetahuan ibu mengenai pendampingan adalah sejumlah informasi yang dapat menambah serta menggugah pemikiran ibu untuk dapat melakukan pendampingan dengan tujuan untuk meningkatkan kualitas hidup anaknya. Terdapat delapan prinsip pendampingan yaitu knowing, alternating rhythms, patience, honesty, trust, humility, hope, dan courage, diharapkan informasi yang diberikan ini dapat menambah pengetahuan ibu sehingga ibu dapat lebih optimal dalam mendampingi anak mild intellectual disability usia 7-10 tahun.

\section{Definisi Operasional}

Pengetahuan ibu mengenai prinsip pendampingan terhadap anak mild intellectual disability dijelaskan sebagai suatu pengetahuan dan pemahaman ibu yang bersifat aplikatif secara kognitif untuk mengaplikasikan prinsip-prinsip pendampingan. Dalam hal ini pendampingan merupakan suatu upaya merawat orang lain yang tidak memaksakan kehendaknya terhadap orang lain melainkan mengikuti arahan perkembangan dari orang lain itu sendiri. Pengetahuan yang diukur dalam penelitian ini mengenai prinsip pendampingan yang meliputi 8 prinsip pendampingan yaitu, knowing, alternating rhythms, patience, honesty, trust, humility, hope, dan courage yang didasarkan pada Mayeroff (1971). Pengetahuan tersebut diukur berdasarkan atas perubahan jumlah skor pengetahuan yang dicapai ibu melalui pretest dan posttest dengan mengunakan alat ukur pengetahuan ibu mengenai prinsip pendampingan mild intellectual disability.
Berdasarkan tabel 2 dijelaskan mengenai definisi masing-masing prinsip pendampingan.

Tabel 2. Prinsip Pendampingan

\begin{tabular}{|c|c|}
\hline $\begin{array}{l}\text { Prinsip Pen- } \\
\text { dampingan }\end{array}$ & Definisi \\
\hline Knowing & $\begin{array}{l}\text { Pengetahuan mengenai perkembangan } \\
\text { yang terjadi pada anak. Dalam pelatihan } \\
\text { ini akan dijelaskan } 4 \text { hal, yaitu: } \\
\text { 1. Intellectual Disability } \\
\text { 2. Mild Intellectual Disability } \\
\text { 3. Karakteristik anak mild intellectual } \\
\text { disability } \\
\text { 4. Peran orangtua bagi anak mild intel- } \\
\text { lectual disability }\end{array}$ \\
\hline $\begin{array}{l}\text { Alternating } \\
\text { Rhythms }\end{array}$ & $\begin{array}{l}\text { Pengetahuan terkait pemahaman ibu } \\
\text { mengenai penggunaan metode atau cara } \\
\text { penyampaian yang berbeda-beda dalam } \\
\text { mendampingi anak guna mencapai } \\
\text { tujuan tertentu. }\end{array}$ \\
\hline Patience & $\begin{array}{l}\text { Pengetahuan mengenai pentingnya } \\
\text { kesabaran dalam pendampingan dan } \\
\text { memahami jika anak akan tumbuh dan } \\
\text { berkembang sesuai waktunya sendiri. }\end{array}$ \\
\hline Honesty & $\begin{array}{l}\text { Pengetahuan mengenai pentingnya ket- } \\
\text { ulusan hati dimana ibu mampu menilai } \\
\text { anak secara objektif. }\end{array}$ \\
\hline Trust & $\begin{array}{l}\text { Pengetahuan mengenai pentingnya pem- } \\
\text { berian kepercayaan terhadap anak dan } \\
\text { kepercayaan terhadap kemampuan serta } \\
\text { kapasitas pada diri ibu sendiri. Dalam } \\
\text { penelitian ini dijelaskan } 2 \text { hal, yaitu: } \\
\text { 1. Pengertian trust dalam pendampingan } \\
\text { 2. Pentingnya trust dalam perkembangan } \\
\text { anak }\end{array}$ \\
\hline Humility & $\begin{array}{l}\text { Pengetahuan mengenai pentingnya ketu- } \\
\text { lusan dan kerendahan hati agar mening- } \\
\text { katkan kesiapan serta keinginan ibu } \\
\text { dalam mempelajari hal baru mengenai } \\
\text { anak maupun dirinya sendiri. }\end{array}$ \\
\hline Hope & $\begin{array}{l}\text { Pengetahuan mengenai pentingnya me- } \\
\text { nerima kondisi anak tanpa memaksakan } \\
\text { kehendak ataupun harapan yang tinggi } \\
\text { terhadap anak. Dalam pelatihan akan } \\
\text { dijelaskan mengenai: } \\
\text { 1. Karakteristik anak mild intellectual } \\
\text { disability dan bagaimana pemahaman } \\
\text { mereka terhadap informasi } \\
\text { 2. Harapan yang dapat dikembangkan } \\
\text { dengan keterbatasan yang dimiliki oleh } \\
\text { anak }\end{array}$ \\
\hline Courage & $\begin{array}{l}\text { Pengetahuan mengenai pentingnya } \\
\text { keberanian untuk lebih terbuka dan peka } \\
\text { pada apa yang sedang terjadi saat ini. }\end{array}$ \\
\hline
\end{tabular}




\section{Teknik Sampling}

Teknik pengambilan sampel partisipan yakni dengan teknik purposive sampling yaitu teknik penentuan sampel dengan mempertimbangkan pada sesuatu. Teknik purposive sampling yang digunakan dalam penelitian ini adalah theory based sampling, yaitu sampel yang dipilih berdasarkan pada teori yang disesuaikan dengan tujuan penelitian.

\section{Karakteristik dan Jumlah Sampel}

Berdasarkan karakteristik umum subjek yang dipilih untuk menjadi partisipan adalah ibu yang memiliki anak mild intellectual disability, dengan kriteria sebagai berikut:

a. Ibu yang memiliki anak dengan mild intellectual disability usia kronologis 7-10 tahun.

b. Tingkat pendidikan ibu minimal SMA, dengan pertimbangan berdasarkan dari hasil penelitian Ling (2008 dalam Rahmawati Dian, 2011) didapatkan bahwa orang tua dengan latar belakang pendidikan dasar dan menengah pertama tidak dapat melatih anak untuk melakukan keterampilan perawatan diri sebaik orang tua dengan latar belakang pendidikan yang lebih tinggi.

c. Ibu belum pernah mengikuti pelatihan mengenai cara pendampingan terhadap anak dengan mild intellectual disability.

d. Ibu belum mengetahui cara pendampingan terhadap anak dengan mild intellectual disability.

e. Bersedia mengikuti seluruh rangkaian program pelatihan prinsip pendampingan dari awal hingga akhir dengan ditunjukkan melalui pengisian lembar kesediaan.

Karakteristik khusus sampel penelitian adalah pembelajaran orang dewasa. Partisipan dalam pelatihan ini merupakan orang dewasa, oleh karena itu pendekatan pembelajaran yang digunakan adalah metode belajar orang dewasa yang memiliki ciri utama keterlibatan secara aktif pada partisipan selama pelatihan berlangsung. Penelitian ini melibatkan 4 (empat) orang partisipan dengan karakteristik diatas.

\section{HASIL DAN PEMBAHASAN}

Pada penelitian ini dilakukan dua tahapan, yaitu perancangan program pelatihan dan ujicoba rancangan program pelatihan. Pada tahap perancangan program pelatihan menggunakan pendekatan instructional design dengan melakukan sembilan tahapan. Selanjutnya dilakukan proses validasi yang dilakukan oleh expert, dua orang psikolog, guna mengkaji validasi program pelatihan yang telah dirancang baik secara konten maupun metode. Adapun beberapa hasil saran perbaikan dari expert, yaitu: pertama, instructional objectives, penjelasan tujuan pelatihan yang masih terlalu umum sehingga perlu dituliskan tujuan instruksional khusus yang berkaitan dengan evaluation instrument. Oleh karena itu diharapkan perilaku yang ditampilkan oleh partisipan selama proses pelatihan dapat terobservasi dan terukur dengan jelas. Kedua, designing the message, perlunya penjelasan yang lebih rinci pada tiap sesi dan memberikan kesempatan kepada partisipan untuk mencoba menerapkan tugas yang diberikan pada pelatihan hari pertama. Ketiga, pertimbangan alokasi waktu dan metode yang tepat untuk menyampaikan materi sehingga partisipan mampu menerima serta memahami seluruh sesi yang diberikan. Keempat, pemberian penjelasan terkait dengan alasan penggunaan metode penyampaian sesi serta menambahkan metode seperti penayangan video dan gambar serta roleplay. Hal ini diperlukan guna memudahkan partisipan dalam menerima serta memahami informasi yang diberikan. Kisi-kisi program pelatihan dilampirkan di akhir tulisan ini.

Setelah dilakukan perancangan program pelatihan maka dilakukan pelaksanaan ujicoba. Pelaksanaan uji coba dilakukan selama dua hari yang masing-masing harinya terdiri atas empat sesi. Sesi pertama berisi mengenai materi knowing, alternating rhytms, patience, dan honesty. Sedangkan pada sesi kedua berisi materi trust, humility, hope, courage.

Diharapkan melalui ujicoba ini didapatkan hipotesis jika terdapat peningkatan pengetahuan ibu mengenai prinsip pendampingan anak mild intelletuctual disability usia 7-10 tahun. Guna menguji hipotesis penelitian tersebut, maka dilakukan analisa statistik dengan menggunakan data hasil pengukuran skor pengetahuan subjek penelitian sebelum dan sesudah mengikuti program pelatihan. Berdasarkan hasil statistik yang dilakukan dengan menggunakan uji beda paired t test, diperoleh hasil seperti pada tabel 3 dibawah ini.

Hasil tersebut menunjukkan bahwa terdapat hasil uji beda ( $p$-value) sebesar 0,004 dengan taraf kepercayaan 0,05 . Nilai hasil uji beda yang berada di bawah taraf kepercayaan menunjukkan bahwa terdapat perbedaan dalam uji beda yang dilakukan. $P$-value sebesar $0,004<0,05$ menunjukkan adanya perbedaan yang signifikan antara skor pengetahuan subjek penelitian saat sebelum dan sesudah pelatihan diberikan. 
Tabel 3. Hasil Uji Statistik Paired T Test

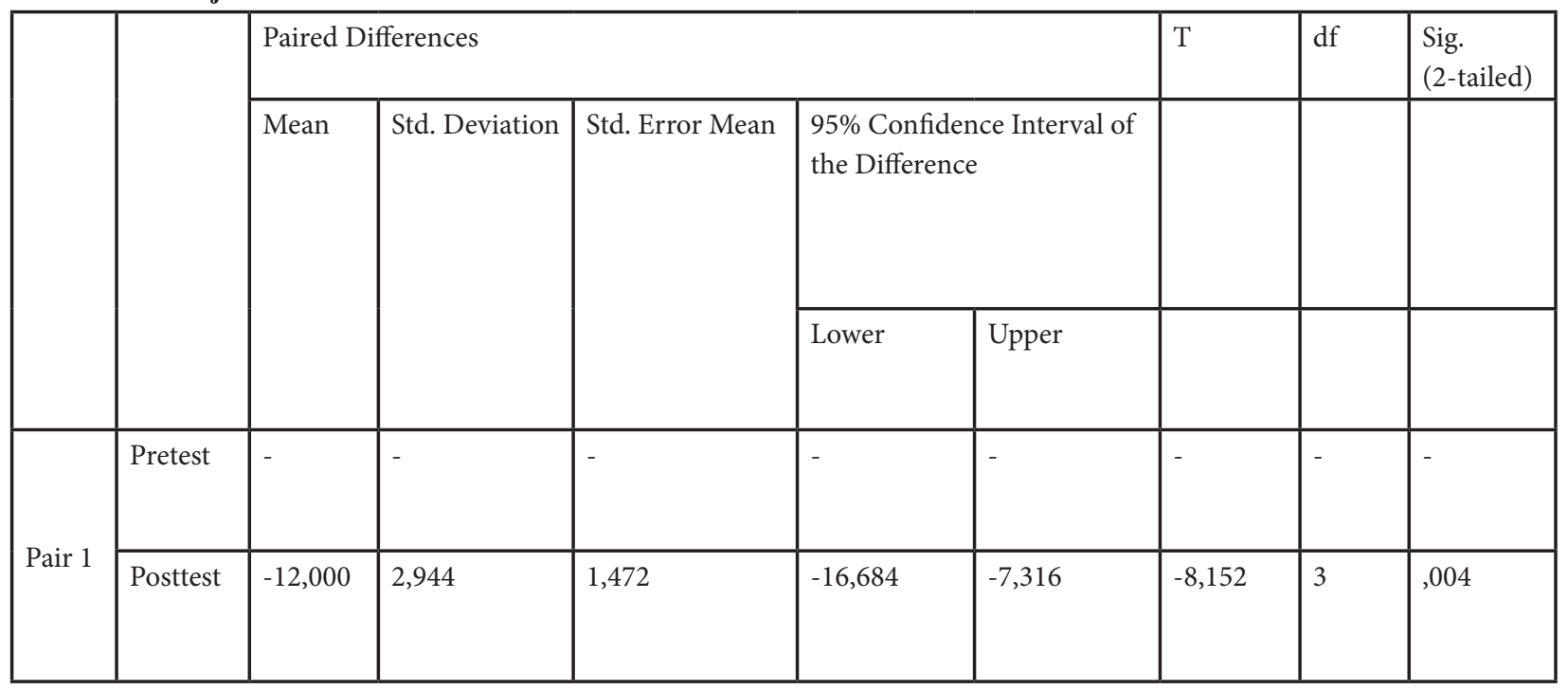

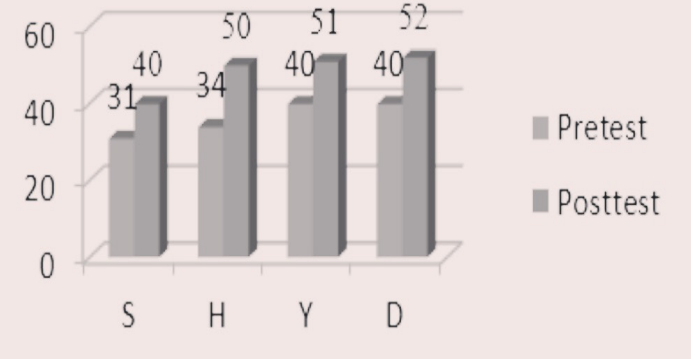

Grafik 1. Hasil Pretest dan Posttest

Berdasarkan pada grafik 1 dapat diketahui jika total skor pengetahuan mengenai keseluruhan sesi pelatihan yang diperoleh keempat partisipan saat pretest telah mengalami peningkatan. Peningkatan yang terlihat paling tinggi tampak pada subjek kedua yang mengalami peningkatan pengetahuan sebesar $27 \%$. Persentase ini menunjukkan jika Keempat partisipan menunjukkan peningkatan skor yang berkisar antara $16-27 \%$.

Berdasarkan hasil ujicoba program pelatihan didapatkan hasil jika terdapat peningkatan pengetahuan ibu yang memiliki anak mild intellectual disability usia 7-10 tahun. Berikut gambaran hasil dari masing-masing partisipan penelitian ini:

Partisipan S, selama pelatihan partisipan menunjukkan antusiasme dan inisiatif untuk berbagi pengalaman mengenai kondisi anaknya. Meski demikian, partisipan $\mathrm{S}$ tampak lebih banyak mendengarkan penjelasan fasilitator dibandingkan melihat materi pada slide. Partisipan melihat ke arah slide hanya ketika pemutaran video atau penjelasan berupa gambar. Partisipan menjelaskan jika tulisan dalam penyajian terlalu kecil sehingga partisipan hanya mendengar dari penjelasan fasilitator.
Selama proses pelatihan tampak jika terdapat beberapa informasi yang baru diperoleh selama pelatihan. Hal ini ditunjukkan dengan beberapa komentar partisipan seperti "oh", "ah iya itu seperti anak saya" yang disertai dengan anggukan kepala. Reaksi partisipan tersebut merupakan salah satu pemrosesan informasi dimana partisipan mengintegrasikan materi yang baru dengan pengetahuan yang telah ibu miliki mengenai anak. Ketika partisipan menemukan penghubung antara materi baru dengan pengetahuan yang telah diketahui, hal ini semakin memudahkan partisipan dalam mengingat materi yang diberikan. Peningkatan skor terbanyak yang berhasil diperoleh partisipan $\mathrm{S}$ adalah bagian $h u$ mility, dimana ibu mampu untuk melihat kondisi anak sepenuhnya bukan melihat bagaimana anak seperti yang diharapkan oleh ibu. Pada awal sesi, ibu menjelaskan jika anaknya nakal dan sulit untuk diberikan nasihat. Partisipan yang belum memahami kondisi anak, pada akhirnya memaksa anak bahkan memukul jika anak tidak melakukan seperti yang ibu kehendaki. Setelah pemberian materi, partisipan mendapatkan kesempatan satu hari untuk mencoba menerapkan pengetahuan yang telah diberikan. Partisipan menjelaskan jika partisipan mulai memahami kondisi anak dengan berusaha memberitahu anak secara perlahan (tidak memukul), perubahan sikap ibu inilah yang turut mengubah sikap anak terhadap ibu. Jika sebelumnya anak melawan ketika diberikan nasihat, namun ketika ibu mampu menjelaskan secara perlahan, anak mampu untuk mendengarkan dan melakukan yang ibu perintahkan. Adanya perubahan sikap anak yang ditunjukkan pada hari jeda (hari antara pelatihan sesi pertama dan kedua) membuat ibu semakin antusias untuk menerima informasi yang diberikan. 
Partisipan H, selama pelatihan partisipan menunjukkan keaktifan dan antusiasme untuk mengikuti pelatihan. Hal ini ditunjukkan sejak pelatihan dimulai, partisipan tampak hadir terlebih dahulu dibandingkan partisipan lainnya. Selain itu pada pelatihan di sesi kedua, hanya partisipan $\mathrm{H}$ yang membawa kembali handout hari pertama. Selama proses pelatihan, partisipan tampak memperhatikan materi yang diberikan dan memberikan catatan tambahan pada handout materi yang dimiliki. Catatan kecil ini merupakan proses encoding yang dapat membantu partisipan dalam mengintegrasikan informasi yang baru diterima dengan pengetahuan yang telah dimiliki sebelumnya. Partisipan $\mathrm{H}$ juga menjelaskan bahwa ia telah mencoba untuk menerapkan sesi yang telah diberikan pada hari pertama kepada anak. Sebelum mengikuti pelatihan partisipan menjelaskan bahwa ia sering merasa tidak sabar dan kesal ketika anak masih belum mampu mandi dengan bersih. Pada akhirnya partisipan selalu memandikan anak agar sesuai dengan harapan partisipan. Namun kemudian partisipan mencoba untuk mengubah cara pemberian instruksi kepada anak dengan lebih perlahan-lahan (break down). Partisipan juga mencontohkan dan anak mampu menirukan yang diperintahkan oleh partisipan. Melalui proses ini, partisipan juga mencoba lebih sabar karena memang anak butuh instruksi yang jelas dan waktu yang lebih lama.

Partisipan Y, selama pelatihan berlangsung, partisipan termasuk yang paling aktif dan antusias dalam mendengarkan dan memberikan tanggapan ketika diberikan pertanyaan. Pada sesi pertama, terkait dengan permainan yang diberikan dalam sesi knowing, partisipan menjelaskan jika pemberian instruksi seharusnya diberikan secara jelas dan ditunjukkan, sehingga tidak ada kesalahan dalam melakukan tugasnya. Kemudian partisipan mendapatkan insight jika anaknya yang tidak paham terkait instruksi yang diberikan, dikarenakan cara ibu yang tidak jelas dan konkrit dalam memberikan arahan. Jika dikaitkan dengan salah satu faktor pembelajaran orang dewasa (andragogy) yaitu transfer of learning, maka pemberian informasi yang sesuai dengan kondisi yang dihadapi partisipan akan lebih memudahkan partisipan dalam mengaplikasikannya ke dalam tugas sehari-hari. Pada sesi kelima, partisipan sempat salah memberikan instruksi sehingga kalah dalam permainan. Kemudian saat berganti peran di babak kedua, partisipan dapat memenangkan permainan. Selama proses debrief, partisipan menjelaskan alasan kekalahannya karena kurang pahamnya terhadap instruksi. Dalam hal ini partisipan menyadari bahwa kesalahan yang selama ini dilakukan oleh anak dikarenakan kurang pahamnya anak terha- dap instruksi yang diberikan oleh partisipan. Partisipan menjelaskan bahwa sebelum mengikuti pelatihan, ia sering memberikan perintah dengan kalimat yang belum konkret, akibatnya anak tidak dapat memahami perintah tersebut. Saat hari jeda pelatihan ini, partisipan mencoba untuk mengubah caranya dalam memberikan instruksi menjadi instruksi yang lebih konkret, diberikan secara berulang, sehingga akhirnya anak mampu mengikuti instruksi yang partisipan berikan.

Partisipan D, jika dibandingkan dengan ketiga partisipan lainnya, partisipan D yang paling tanggap dan tepat dalam memberikan jawaban baik secara konseptual maupun praktikal. Hal ini dikarenakan dibandingkan dengan partisipan lainnya, partisipan D yang paling aktif dalam mencari informasi terkait dengan anak disabilitas, hal ini dikarenakan partisipan memiliki 2 anak dan keduanya adalah anak berkebutuhan khusus. Selama pelatihan berlangsung, partisipan menjelaskan jika metode gambar memudahkan partisipan dalam memahami informasi. Hal ini jika dikaitkan dengan pemrosesan informasi yaiitu pada bagian encoding. Sebelum mengikuti pelatihan, partisipan menjelaskan jika ibu memiliki kekhawatiran terhadap anak sehingga seringkali anak tidak mendapatkan kesempatan untuk menocba melakukan aktivitasnya sendiri. Kemudian partisipan mencoba memberikan kepercayaan kepada anak, anak mampu untuk melakukan kegiatannya sendiri bahkan lebih baik dibandingkan ketika diawasi atau diperhatikan oleh partisipan.

Berdasarkan hasil ujicoba program pelatihan didapatkan beberapa hal yang mampu membantu partisipan dalam memahami materi yang diberikan. Pertama, media gambar dan metode bermain. Pada metode dengan media gambar ataupun video, partisipan lebih mudah mencerna informasi yang telah dijelaskan. Salah satu partisipan menjelaskan bahwa ia mengingat materi di hari pertama dikarenakan media gambar yang dijelaskan pada salah satu materi. Selain itu, beberapa partisipan juga memberikan komentar ketika menonton video. Mereka jadi lebih memahami dan mengerti penjelasan dari materi yang disampaikan setelah selesai menonton video. Selain kedua metode penyampaian di atas, metode games juga merupakan salah satu metode yang mampu untuk mencairkan suasana sehingga lebih santai dan lebih memudahkan partisipan dalam memahami materi. Saat proses debrief, beberapa partisipan mampu memberikan jawaban sesuai dengan maksud dari pemberian permainan tersebut yang terkait dengan materi. Partisipan terlihat tampak lebih memahami materi yang disajikan melalui metode permainan. Kedua, mengga- 
bungkan materi yang disampaikan dengan pengalaman masing-masing individu. Berdasarkan pada prinsip andragogi yang disampaikan oleh Knowles (2005) bahwa partisipan memiliki berbagai pengalaman dalam kaitannya mendampingi anak mild intellectual disability. Pengalaman yang partisipan miliki dapat menjadi salah satu sumber dan bahan belajar serta mendukung sistem pembelajaran. Dengan demikian, menggabungkan materi yang disampaikan dengan pengalaman diri ternyata lebih memudahkan partisipan dalam memahami materi yang diberikan. Ketiga, penggunaan metode yang berbeda-beda (diskusi, gambar, video, games). Penggunaan metode yang berbeda-beda dalam setiap sesinya membuat partisipan tidak merasa bosan dan lebih memahami materi yang diberikan. Menurut (Lunandi, 1987) pembelajaran dengan cara mendengarkan saja merupakan cara yang kurang efektif dibandingkan beberapa cara lainnya.

Selain itu, perbedaan hasil peningkatan skor pengetahuan yang diperoleh partisipan dapat dikaji menggunakan teori pemrosesan informasi (Glisky, 2007) yang akan diuraikan sebagai berikut:

Pertama, atensi. Pada pelatihan ini, tiap partisipan memiliki rentang atensi yang berbeda-beda. Ada beberapa partisipan yang mampu untuk mempertahankan atensinya selama pelatihan berlangsung, meskipun ada gangguan suara dari lingkungan sekitar pelatihan. Namun ada juga beberapa partisipan yang mudah teralihkan dengan suara-suara di luar penjelasan materi dalam pelatihan.

Kedua, persepsi. Hal ini dikarenakan perbedaan pengalaman, pengetahuan, kemampuan, dan lain-lain sehingga informasi yang ditangkap oleh sensory memory akan ditransfer ke dalam short term memory juga akan berbeda. Aspek penting dari short term memory, selain terbatasnya durasi penyimpanan maupun kapasitas yaitu peran dari working memory. Dalam konteks working memory, short term memory akan berperan sebagai tempat untuk menyimpan sementara. Ketika terjadi pengulangan informasi dan ketika partisipan mengintegrasikan materi baru yang diterima dengan pengetahuan yang telah dimiliki, maka informasi tersebut akan masuk ke dalam long term memory.

Ketiga, encoding (penyandian informasi). Pada pelatihan ini, fasilitator memberikan media berupa gambar, video, ataupun tulisan bercetak tebal yang diharapkan dapat memudahkan partisipan dalam memahami materi yang diberikan. Meski demikian, penyandian informasi antara masing-masing partisipan berbeda-beda. Ada yang lebih mengingat materi yang diberikan melalui media gambar, namun ada pula yang memberikan catatan kecil pada handout yang telah diterima.
Selain itu, beberapa partisipan juga tampak kesulitan dalam menyebutkan istilah penamaan prinsip pendampingan seperti perubahan irama, kerendahan hati, dan ketulusan hati. Hal ini dikarenakan, perbendaharaan kata yang digunakan dalam penamaan prinsip pendampingan merupakan kata yang jarang didengar dalam kehidupan sehari-hari. Sebaliknya, pada prinsip pendampingan pengetahuan, kesabaran, kepercayaan, harapan, dan keberanian, partisipan dapat menyebutkan nama prinsip pendampingan tersebut dengan tepat. Penyandian informasi tersebut lebih mudah dipahami karena istilah yang dipergunakan sudah biasa didengar dalam kehidupan sehari-hari partisipan.

Keempat, perbedaan usia. Dalam pemrosesan informasi, perbedaan usia dapat menjadi salah satu faktor penghambat individu menerima dan mengingat suatu informasi. Partisipan yang memiliki usia lebih tua akan kesulitan dalam menjelaskan suatu konsep yang diberikan jika tidak dibantu dengan adanya suatu petunjuk. Pada penelitian ini, partisipan diminta untuk menerapkan pengetahuannya ketika mendampingi anak mild intellectual disability di rumah. Ketika menjalankan tugas di rumah, keempat partisipan telah mencoba untuk menerapkan materi yang telah diajarkan di hari pertama, kendala apa saja yang dihadapi, dan perubahan apa saja yang terjadi. Hasilnya telah tercantum pada narasi masing-masing partisipan di atas.

\section{SIMPULAN}

Rancangan program pelatihan Padjadjaran-Mayeroff Caring Principles dapat meningkatkan pengetahuan ibu yang memiliki anak mild intellectual disability usia 7-10 tahun. Adapun rata-rata peningkatan pengetahuan partisipan sebesar $21 \%$.

\section{DAFTAR PUSTAKA}

American Psychologist Association. (2013). Diagnostic and Statistical Manual of Mental Disorders (DSM-5). Washington DC: American Psychologist Association

Anderson, L, W; Krathwohl, D. (2001). A Taxonomy for Learning, Teaching, and Assessing: A Revision of Bloom's Taxonomy of Educational Objectives. New York: Addison Wesley Lonman Inc

Bloom, B, S. (1956). Taxonomy of Educational Objectives: The Classifications of Educational Goals. London: Longmans, Green and Co

Christensen, L. B. (2011). Research Methods, Design, And Analysis: Eleventh Edition. New York: Pearson

Glisky. Elizabeth, L. (2007). Brain Aging Models Meth- 
ods and Mechanism. Florida: CRC Press

Goodwin, C. J. (2010). Research in psychology: Methods and design (6th ed.). United States: John Wiley \& Sons.

Graziano, A, M; Raulin, M, L. (2014). Research Methods A Process of Inquiry: Eighth Edition. USA: Pearson

Hunt, D, P. (2003). The Concept of Knowledge and How to Measure it. Journal of Intellectual Capital. Vol 4, No. 1

Issawi, S; Dauphin, B. (2017). Industry Versus Inferiority. Springer International Publishing.

J. W. Jacobson and J. A. Mulick. (1996). Manual of diagnosis and professional practice in mental retardation. Washington DC, US.: American Psychological Association

Kirkpatrick, Donald L \& Kirkpatrick, James D. (2008). Evaluating Training Programs: Four level. San Fransisco ; Berrett-Koehler Publishers, Inc

Kirkpatrick, Donald L \& Kirkpatrick, James D. (2007). Implementing The Four Level: A Practical Guide for Effective Evaluation of Training Programs. San Fransisco: Berrett-Koehler Publishers, Inc

Knowles, M, S; Holton III, E, F' Swanson, R, A. (2005). The Adult Learner: Sixth Edition. USA: Elsevier Inc

Lawson, K. (2006). The Trainer's Handbook: 2nd Edition. United States: John Wiley \& Sons, Inc
Lidanial. (2016). Problematika yang Dihadapi Keluarga dari Anak dengan Intellectual Disability (Studi Etnografi). Universitas Pendidikan Indonesia. ISSN 1412-565 X.

Lunandi, A, G. (1987). Pendidikan Orang Dewasa. Jakarta: Gramedia

Masadeh, Mousa. (2012). Training, Education, Development And Learning: What is The Difference? European Scientific Journal. ISSN: 1857-7881, Vol.8, No. 10

Mash, Eric J \& David A.Wolfe. (2010). Abnormal Child Psychology. Fourth Edition. USA: Wadsworth Cengage Learning

Mayeroff, Milton. (1971). On Caring. United Stated: HarperPerennial

Morrison, G, R; Ross, S, M; Kemp, J, E. (2001). Designing Effective Instruction: 3rd Edition. United States: John Wiley \& Sons, Inc

Rahmawati, D. (2011). Faktor-Faktor Yang Berhubungan Dengan Kemampuan Perawatan Diri Anak Tuna Grahita Di Kabupaten Banyumas Jawa Tengah. Skripsi. Universitas Indonesia

Vani, G, C; Raharjo, S, T; Hidayat, E, N. (2015). Pengasuhan (Good Parenting) Bagi Anak dengan Disabilitas. Isu-Isu Kontemporer Bidang Praktek Pekerjaan Sosial, Kesejahteraan Sosial, Profesi Pekerjaan Sosial. Sumedang: Unpad Press 